\title{
REVISION CLINICAL OPTICS
}




\title{
REVISION CLINICAL OPTICS
}

\author{
Montague Ruben \\ and \\ E. Geoffrey Woodward
}

Drawings by

Terry Tarrant 
Text () Montague Ruben and E. Geoffrey Woodward 1982

Illustrations (C) Terry Tarrant 1982

Softcover reprint of the hardcover 1st edition 1982

All rights reserved. No part of this publication may be reproduced or transmitted, in any form or by any means, without permission.

First published 1982 by

THE MACMILLAN PRESS LTD

London and Basingstoke

Companies and representatives throughout the world

ISBN 978-0-333-30705-2 ISBN 978-1-349-16806-4 (eBook)

DOI $10.1007 / 978-1-349-16806-4$

The paperback edition of the book is sold subject to the condition that it shall not, by way of trade or otherwise, be lent, resold, hired out, or otherwise circulated without the publisher's prior consent in any form of binding or cover other than that in which it is published and without a similar condition including this condition being imposed on the subsequent purchaser. 


\section{Preface}

This text was first published almost twenty years ago by the Institute of Ophthalmology, London, for the use of postgraduate students taking the D.O. course. Prof. Montague Ruben selected and designed the drawings, which were drawn by Mr T. Tarrant.

A second edition some years later included a short text for each drawing, but it has long since been out of print.

The present text is designed as a revision text to supplement courses on ophthalmic optics and does not pretend to replace textbooks recommended by teachers. It may be of use to the student who is preparing for examinations in ophthalmology, optometry or orthoptics, and provides a quick method of revision; in particular it will enable the student to discover areas where further tutorials, or the reading of larger texts, are required. The new text has been coauthored by Dr Geoffrey Woodward, thus combining the attitudes of ophthalmologist and optometrist. The text has been enlarged and revised by including physiological optics and most instruments in current use.

London, 1982

M.R.

E.G.W. 


\section{Acknowledgements}

We have been fortunate in obtaining once again the services of Mr Terry Tarrant who has done all the drawings.

The diagrams on pp. 149 to 151 were prepared with the help of Dr M. Guillon, PhD, FBOA.

The authors wish to thank the Institute of Ophthalmology for permission to use the original drawings of Diagrammatic Outline of Clinical Optics, by M. Ruben and T. Tarrant, second edition, 1966. 


\section{Contents}

Preface $\quad \mathrm{v}$

Acknowledgements vi

\section{SECTION I \\ PHYSIOLOGICAL OPTICS}

Absolute Threshold 3

Definition 3

Transmittance of Cornea 5

Lattice Theory 6

Transmittance of the Human Lens at Various Ages 7

Transmittance of Ocular Media 8

The Stiles-Crawford Effect 9

$\begin{array}{ll}\text { Adaptation } & 10\end{array}$

Definition 11

Cone (foveal) dark adaptation $\quad 11$

Rod (peripheral) dark adaptation $\quad 11$

Cone and rod combined to produce a typical dark adaptation curve 12

Factors which slow adaptation $\quad 12$

$\begin{array}{ll}\text { Method of measurement (Goldman adaptometer) } & 12\end{array}$

Rise in Dark Adaptation Threshold in Vitamin A Starvation 13

Dark Adaptation of Different Parts of the Retina 14

$\begin{array}{ll}\text { Purkinje Shift } & 15\end{array}$

The Pulfrich Phenomenon 16

$\begin{array}{ll}\text { The Critical Frequency of Flicker } & 17\end{array}$ 
$\begin{array}{lr}\text { After-Images } & 18\end{array}$

$\begin{array}{ll}\text { Saccadic Suppression } & 19\end{array}$

Field of Vision - Isopters $\quad 20$

$\begin{array}{ll}\text { Traquair's Island } & 21\end{array}$

Field Analyser (Goldman Type) 22

$\begin{array}{ll}\text { Colour Vision } & 23\end{array}$

$\begin{array}{ll}\text { The CIE chromaticity diagram } & 23\end{array}$

$\begin{array}{ll}\text { The anomaloscope (Nagel) } & 24\end{array}$

$\begin{array}{ll}\text { Colour-vision tests } & 26\end{array}$

\begin{tabular}{ll} 
Visual Acuity & 28 \\
\hline & 28
\end{tabular}

$\begin{array}{ll}\text { Resolution } & 28\end{array}$

The Snellen system of recording visual acuity $\quad 30$

Visual acuity and level of illumination $\quad 31$

Variation of visual acuity across the retina 33

Relationship between threshold visual angle and

$\begin{array}{ll}\text { Optokinetic drum } & 35\end{array}$

\section{SECTION II}

\section{BASIC OPTICS}

Sign Convention $\quad 39$

$\begin{array}{ll}\text { Diffraction of Light } & 40\end{array}$

Interference and Wave Motion $\quad 41$

Diffraction from a Thin Film 42

$\begin{array}{ll}\text { Polarisation } & 43\end{array}$

Polariser Prism 44

Reflection of Light $\quad 45$

The Law of Refraction (Snell's Law) 48

Reduced vergence $\quad 51$

The critical angle $\quad 52$

Refraction by a prism $\quad 53$

Prism Dioptre $\quad 55$

Refraction at a Curved Surface $\quad 56$

$\begin{array}{ll}\text { Change of Vergence at a Curved Surface } & 57\end{array}$

Principal rays, focal points and other conjugate points 58 
$\begin{array}{ll}\text { The Lens } & 59\end{array}$

$\begin{array}{ll}\text { Image formation } & 60\end{array}$

$\begin{array}{ll}\text { Rays from extra-axial points } & 61\end{array}$

$\begin{array}{ll}\text { The cylindrical lens } & 62\end{array}$

The sphero-cylinder $\quad 64$

$\begin{array}{ll}\text { Stürm's conoid } & 65\end{array}$

$\begin{array}{ll}\text { Thick lens principal points } & 66\end{array}$

\section{SECTION III \\ CLINICAL OPTICS}

$\begin{array}{ll}\text { Back Vertex Power } & 69\end{array}$

$\begin{array}{ll}\text { Thick Lens Shapes or Forms } & 70\end{array}$

$\begin{array}{ll}\text { Toric Surfaces and Lenses } & 71\end{array}$

$\begin{array}{ll}\text { Prism-Induced Effect } & 72\end{array}$

$\begin{array}{ll}\text { Thin Lens Forms } & 73\end{array}$

$\begin{array}{ll}\text { Positive lenses } & 73\end{array}$

$\begin{array}{ll}\text { Negative lenses } & 74\end{array}$

$\begin{array}{ll}\text { Refraction by a Lens } & 75\end{array}$

Using the principles of tangents and prisms $\quad 75$

$\begin{array}{ll}\text { Refraction by two lenses } & 76\end{array}$

$\begin{array}{ll}\text { Magnification of Objects } & 77\end{array}$

$\begin{array}{ll}\text { Simple microscope } & 77\end{array}$

$\begin{array}{ll}\text { Image Formation with a Negative Lens } & 78\end{array}$

$\begin{array}{ll}\text { Reflection } & 79\end{array}$

$\begin{array}{ll}\text { From a curved convex surface } & 79\end{array}$

$\begin{array}{ll}\text { From a curved concave surface } & 81\end{array}$

From the eye's curved surfaces $\quad 82$

$\begin{array}{ll}\text { Aberrations } & 84\end{array}$

From curved surface refraction - spherical aberrations $\quad 84$

$\begin{array}{lr}\text { From lenses } & 85\end{array}$

Oblique astigmatism $\quad 86$

$\begin{array}{lr}\text { Magnification distortion } & 87\end{array}$

$\begin{array}{ll}\text { Prism aberration } & 88\end{array}$

$\begin{array}{lr}\text { Effective Power } & 89\end{array}$

$\begin{array}{lr}\text { Power in different planes } & 89\end{array}$

$\begin{array}{lr}\text { Power of a lens } & 90\end{array}$ 
Near and Distance Fixation and Ocular Refraction 91

$\begin{array}{ll}\text { Myopia } & 91\end{array}$

Hyperopia $\quad 92$

Multivision Spectacle Lenses $\quad 93$

$\begin{array}{lr}\text { Bifocals } & 95\end{array}$

$\begin{array}{lr}\text { Multifocals } & 100\end{array}$

$\begin{array}{lr}\text { Fitting } & 102\end{array}$

\section{SECTION IV}

VISUAL OPTICS

The Schematic (Average) Eye 105

The Emmetropic and Ametropic Eye 106

$\begin{array}{ll}\text { Ametropia } & 107\end{array}$

Correction of ametropia 109

Correction of hyperopia 111

Ocular Astigmatism 112

Retinal Image Size (R.I.S.) (Spectacle Magnification) 113

Axial Myopia and Magnification of Image 114

Relative Magnification and Myopia 115

Magnification of Images in Myopia 116

$\begin{array}{ll}\text { Aphakia } & 117\end{array}$

Temporary aphakia spectacles 118

Magnification with correction $\quad 118$

$\begin{array}{ll}\text { Aphakia and Retinal Image Magnification } & 120\end{array}$

Pseudo-lens plastic implant $\quad 121$

Pseudo-lens implant powers $\quad 122$

Fixation Axis Relationship to Optic Axis 123

Accommodation 124

Accommodation and Hyperopia 125

Depth of Focus 126

\section{SECTION V}

INSTRUMENTS

Focimeter to Measure Lens Power (The Lensometer) 131

Woolaston Prism Used for Doubling the Image 134 
The Ophthalmoscopy of the Emmetropic Eye 135

Direct Opthalmoscopy 136

Use as visuscope and optometer 136

Use for fixation location and slit beam $\quad 137$

Pleoptoscope 138

Slit-beam projection 138

Optical magnification in emmetropia 138

Magnification in myopia 139

Indirect Ophthalmoscopy 140

The observation system and magnification $\quad 140$

Self-illuminated binocular instrument 142

Fundus Camera 143

Objective Refraction 144

Retinoscopy 144

Automated instrumentation $\quad 149$

Humphrey's Subjective Refractometer 152

Astigmatism 153

Jackson's cross-cylinder 153

The pin-hole and the Scheiner disc 154

Compound Microscope 155

Slit-Lamp Microscope 156

The Corneal Pachometer 157

Zoom-Lens Principle 158

Operation Microscope (Zoom) 159

$\begin{array}{ll}\text { Telescopes } & 160\end{array}$

Javal Schiotz 'Keratometer' (Ophthalmometer) 162

Placido Disc Keratoscope (Klein-Keeler) 164

The Photokeratoscope (The Wesley-Jessen P.E.K.) 164

Contact Lenses 165

Measurement of back curves of contact lens 169

The Radiuscope (Using Drysdale's Principle) 170

$\begin{array}{ll}\text { Sagitta } & 171\end{array}$

Sagitta system applied to radius measurement of contact lenses 172 
Gonioscope Contact Lens

Various Miniature Gonioscopes and Fundus-Viewing

Contact Lenses

Fundus-viewing contact lens

Applanation Tonometer

176

Specular Microscopy

\section{SECTION VI}

\section{BINOCULAR VISION}

Horopter

Panum's Area

Crossed and Uncrossed Diplopia

Diplopia in Strabismus

Change of Apparent Size of Objects with Convergence and Divergence

Stereoscopes 184

Mirror Stereoscopes 185

Aniseikonia (Image Size Difference) 186

Synoptophore (Haploscope)

Maddox Rod

Prism Effect of Spectacles

Convergence

\section{SECTION VII}

MISCELLANEOUS

Exophthalmometer (Hertel)

193

Magnifying Aids

194

Coherent Light and Laser

195

Fresnel's Principle 